\title{
EDUKASI PENCEGAHAN PENULARAN VIRUS CORONA DAN PEMBERDAYAAN MASYARAKAT MEMPRODUKSI JAMU KEKEBALAN TUBUH DI KELURAHAN INDRO, GRESIK
}

\section{EDUCATION FOR PREVENTION OF CORONA VIRUS TRANSMISSION AND COMMUNITY EMPOWERMENT TO PRODUCE JAMU OF BODY IMMUNE IN INDRO VILLAGE}

\author{
Nursela Putri Andian, Pressa Perdana Surya Saputra* \\ Universitas Muhammadiyah Gresik \\ *Email: pressa@umg.ac.id \\ (Diterima 26-01-2021; Disetujui 19-03-2021)
}

\begin{abstract}
ABSTRAK
Pengabdian kepada masyarakat Universitas Muhammadiyah Gresik merupakan salah satu penerapan dari Tri Dharma Perguruan Tinggi. Pengabdian kepada masyarakat ini dilaksanakan untuk membantu masyarakat dalam menghadapi virus corona. Virus Corona adalah penyakit menular yang disebabkan oleh jenis coronavirus yang menyerang imunitas tubuh. Virus Corona menyebabkan sebagian penderitanya mengalami nyeri, hidung tersumbat, konjungtivitis, sakit kepala, diare, sakit tenggorokan, kehilangan indera penciuman atau perasa, perubahan warna kaki atau jari tangan atau ruam di kulit. Virus Corona memerlukan penanganan yang cepat dan tepat. Di sisi lain banyak terdapat tanaman dan ramuan yang berkhasiat sebagai penguat kekebalan tubuh yang belum dikembangkan oleh masyarakat setempat, sehingga perlu diperkenalkan kembali pada masyarakat terutama ibu-ibu Kelurahan Indro, Kebomas, Gresik. Mengingat peran ibu dalam menjaga kesehatan keluarga sangatlah penting. Tujuan dari kegiatan ini adalah untuk mendidik dan memberdayakan ibu-ibu Kelurahan Indro untuk mendayagunakan ramuan jamu tradisional dalam pencegahan Virus Corona. Pendekatan yang digunakan dalam kegiatan ini adalah penyuluhan tentang pencegahan Virus Corona serta ramuan jamu untuk penguat kekebalan tubuh. Akhirnya, kegiatan ini dinilai mampu meningkatkan pengetahuan dan keterampilan ibu-ibu kelurahan Indro tentang pencegahan virus corona dan pembuatan jamu kekebalan tubuh untuk pencegahan Virus Corona.
\end{abstract}

Kata kunci: Virus Corona, Pemberdayaan, Jamu, Pengetahuan, Keterampilan

ABSTRACT

Community service at the University of Muhammadiyah Gresik is one of the applications of the Tri Dharma of Higher Education. This community service is carried out to help the community in dealing with the corona virus. Corona virus is an infectious disease caused by a type of coronavirus that attacks the body's immunity. The Corona virus causes some sufferers to experience pain, nasal congestion, conjunctivitis, headaches, diarrhea, sore throat, loss of smell or taste, discoloration of feet or fingers or rashes on the skin. Corona virus requires fast and precise handling. On the other hand, there are many plants and potions that have immuneboosting properties that have not been developed by the local community, so they need to be reintroduced to the community, especially women in Indro Village, Kebomas, Gresik. Remembering the role of mothers in maintaining family health is very important. The purpose of this activity is to educate and empower Indro Village mothers to utilize traditional herbal concoctions in the prevention of the Corona Virus. The approach used in this activity is counseling on the prevention of Corona Virus and herbal concoctions for immune booster. Finally, this activity is considered to be able to increase the knowledge and skills of Indro subdistrict mothers about the prevention of the corona virus and the manufacture of immune herbal medicine for the prevention of the Corona Virus.

Keywords: Corona Virus, Empowerment, Herbalism, Knowledge, Skills

\section{PENDAHULUAN}

Virus Corona merupakan bagian dari keluarga virus yang menyebabkan penyakit pada hewan ataupun juga pada manusia. Di Indonesia, masih dalam status melawan Virus Corona hingga saat ini, begitu pun juga di negara lainnya. Jumlah terinfeksi Virus Corona 
Edukasi Pencegahan Penularan Virus Corona dan Pemberdayaan Masyarakat Memproduksi Jamu Kekebalan Tubuh di Kelurahan Indro, Gresik

Nursela Putri Andian, Pressa Perdana Surya Saputra

semakin banyak dengan jumlah kesembuhan, dan korban meninggal yang juga meningkat. Usaha pencegahan oleh pemerintah terus dilakukan untuk menekan penyebaran COVID19. gejalanya diawali dengan radang paru-paru atau pneumonia misterius pada bulan Desember 2019 di Wuhan, Tiongkok, Cina. Kasus awal ini banyak ditemukan di daerah pasar hewan wuhan. Pasar hewan wuhan tersebut menjual bermacam-macam daging hewan, termasuk yang tidak sewajarnya dikonsumsi seperti kelelawar, ular, dan jenis-jenis tikus COVID-19 ini diduga dibawa oleh kelelawar atau jenis hewan lainnya. Selanjutnya menular ke manusia akibat pengkonsumsian hewan tersebut. Dengan latar belakang tersebut, COVID-19 telah membuat warga dunia panik. Karena mempunyai sifat yang mirip seperti Flu, COVID-19 menyebar dengan cepat hingga ke seluruh negara.

Kelurahan Indro, Kecamatan Kebomas, Kabupaten Gresik merupakan salah satu lokasi pengabdian 2020 Universitas Muhammadiyah Gresik. Pada kegiatan pengabdian ini difokuskan kepada masyarakat Kelurahan Indro khususnya pada ibu-ibu PKK. Mengingat seorang ibu merupakan garda terdepan dalam menjaga kesehatan keluarga. Jika pengetahuan ibu terhadap kesehatan meningkat, maka kesehatan dalam keluarga pun meningkat. Hal itu karena gerakan PKK ini bertujuan memberdayakan dan meningkatkan kesejahteraan keluarga sehingga terciptanya keluarga yang beriman dan bertaqwa kepada tuhan yang maha esa, berbudi luhur dan berakhlak mulia, maju, sehat sejahtera, dan mandiri, keadilan dan kesetaraan gender serta kesadaran lingkungan dan hukum. Tim Penggerak PKK bertugas memotivasi, memfasilitasi, merencanakan, melaksanakan, mengendali dan menggerakkan pengetahuan dan keterampilan sehingga tujuan kegiatan pengabdian ini akan lebih terwujud jika langsung ditujukan pada ibu-ibu PKK dari pada masyarakat secara umum, tentang cara pencegahan Virus Corona dan pembuatan ramuan jamu penguat kekebalan tubuh

\section{METODE PELAKSANAAN}

Pengabdian kepada masyarakat ini meliputi:

\section{A. Onlineisasi}

Kegiatan ini bertujuan penyuluhan melalui media sosial. Kegiatan tersebut mempunyai sasaran ibu-ibu PKK di Kelurahan Indro. Ibu-ibu diberikan penyuluhan tentang virus corona dan cara pencegahannya agar paham dan mampu memberikan penyuluhan terhadap keluarganya. Selain diberikan materi tentang Virus Corona, ibu-ibu PKK juga diberikan penyuluhan cara pembuatan ramuan jamu, pengemasan dan penjualan jamu penguat kekebalan tubuh. 


\section{B. Perencanaan Kegiatan}

Perencanaan kegiatan dilakukan setelah pelaksanaan onlineisasi dilakukan, tetapi terlebih dahulu memerlukan data ibu-ibu PKK Kelurahan Indro yang bersedia mengikuti program pengabdian ini.Agar program ini berjalan secara maksimal, maka diperlukan perencanaan secara tepat, diantaranya:

1. Mengamati pentingnya mengadakan program Karena Penyebaran Virus Corona semakin meluas.

2. Menyusun waktu dan tempat pelaksanaan kegiatan

3. Mempersiapkan media dalam memberikan penyuluhan

4. Melakukan pendampingan dan pembagian tugas kepada ibu-ibu PKK Kelurahan Indro.

\section{Pelaksanaan}

Metode pelaksanaan

1. Tim pengabdi menyiapkan media dan peralatan yang digunakan dalam melaksanakan kegiatan penyuluhan Pencegahan Virus Corona.

2. Tim pengabdi memberikan pelatihan cara pembuatan jamu kekebalan tubuh mulai dari tahap pembuatan, pengemasan sampai pejualan.

3. Ibu-ibu PKK mempraktikkan pembuatan jamu kekebalan tubuh mulai dari tahap pembuatan, pengemasan sampai pejualan.

4. Tim pengabdi memantau kegiatan pemberdayaan ibu-ibu PKK berjalan dengan konsisten.

\section{Teknik Pelaksanaan}

Pelaksanaan kegiatan Pengabdian kepada Masyarakat ini dilaksanakan dengan metode tutorial, dan diskusi. Adapun teknik pelaksanaan kegiatan pengabdian ini adalah sebagai berikut:

1. Langkah 1 (Metode Observasi):

Tim pengabdi melakukan observasi di beberapa Wilayah RT (Rukun Tetangga) di Kelurahan Indro. Kegiatan ini bertujuan untuk memilih wilayah RT yang mayoritas Ibuibu tidak bekerja. Karena ibu-ibu yang tidak bekerja memiliki lebih banyak waktu dibandingkan dengan ibu-ibu yang bekerja. Sehingga kegiatan pengabdian mengenai penyuluhan Pencegahan Virus Corona diharapkan menarik banyak partisipan khususnya ibu-ibu Rumah Tangga. 
Edukasi Pencegahan Penularan Virus Corona dan Pemberdayaan Masyarakat Memproduksi Jamu Kekebalan Tubuh di Kelurahan Indro, Gresik

Nursela Putri Andian, Pressa Perdana Surya Saputra

\section{Langkah 2 (Metode Tutorial):}

Ibu-ibu Kelurahan Indro diberikan materi tentang pencegahan Virus Corona dan pembuatan jamu kekebalan tubuh mulai dari tahap pembuatan, pengemasan sampai pejualan. Kegiatan ini bertujuan untuk memperdalam pengetahuan dan keterampilan ibuibu Kelurahan Indro.

\section{Langkah 3 (Metode Diskusi):}

Ibu-ibu Kelurahan Indro diberikan kesempatan untuk mendiskusikan permasalahan yang berkaitan dengan pencegahan Virus Corona dan pembuatan jamu kekebalan tubuh mulai dari tahap pembuatan, pengemasan sampai pejualan.

\section{E. Monitoring dan Evaluasi}

Monitoring dan evaluasi dilaksanakan untuk mengetahui perkembangan pelaksanaan kegiatan pengabdian, dan menilai kesesuaian kegiatan yang telah dilaksanakan dengan perencanaan. Evaluator kegiatan ini adalah Tim pengabdi. Evaluator dapat juga berfungsi sebagai motivator bagi ibu-ibu dalam meningkatkan pemahaman dan pengimplementasian kegiatan yang berkaitan dengan pencegahan Virus Corona dan pembuatan jamu kekebalan tubuh mulai dari tahap pembuatan, pengemasan sampai pejualan agar berjalan sesuai rencana.

Hasil yang dicapai yakni respon para ibu-ibu warga RT 6 Kelurahan Indro sangat baik, dan mereka mau mencoba untuk mengaplikasikannya. Akan tetapi hambatannya adalah kegiatan ini tidak selalu berjalan sesuai rencana, karena bergantung pada waktu luang ibuibu. Adapun untuk tindak lanjut dari kegiatan utama ini adalah diharapkan ke depannya mereka tetap konsisten dalam menjalankan kegiatan pencegahan Virus Corona dan bisnis penjualan jamu kekebalan tubuh sehingga ibu-ibu RT 6 Kelurahan Indro bisa menyadari pentingnya pencegahan daripada pengobatan.

\section{HASIL DAN PEMBAHASAN}

Kegiatan pertama dilaksanakan pada hari Senin, 27 Juli 2020 yaitu meminta izin melaksanakan kegiatan pengabdian di kelurahan Indro. Kegiatan selanjutnya mengumpulkan data ibu-ibu PKK yang tinggal di wilayah RT 6 Kelurahan Indro. Pada tanggal 2 Agustus 2020 melakukan kegiatan penyuluhan di media sosial yang membahas tentang pencegahan Virus Corona dan cara membuat jamu penguat kekebalan tubuh. 
Pada tangga 16 Agustus 2020 kegiatannya adalah membeli bahan baku dan peralatan untuk memproduksi jamu kemasan siap saji penguat kekebalan tubuh bersama ibu-ibu RT 6 Kelurahan Indro yang bergabung dalam kegiatan memproduksi jamu.

Kegiatan selanjutnya adalah Survey lapangan. Survey pertama kami dilaksanakan pada hari Senin, 10 Agustus 2020. Kegiatan ini dilaksanakan dengan cara mendatangi setiap rumah ibu-ibu RT 6 yang terlibat dalam menjalankan bisnis penjualan jamu kekebalan tubuh, dengan tujuan agar kami dapat mengetahui secara langsung bagaimana proses pembuatan jamu berlangsung. Di RT 6 Kelurahan Indro ibu-ibu yang bergabung dalam menjalankan bisnis ini terdapat 5 orang, yaitu Ibu Yuliatun, Ibu Rubiatun, Ibu Yati, Ibu Yuni dan Ibu Reni. Rasa jamu yang dihasilkan dari beberapa ibu-ibu tersebut relatif sama, karena takaran bahan dan waktu masak telah didiskusikan oleh mereka. Namun ada beberapa hal yang tidak diperhatikan oleh ibu-ibu tersebut yaitu tidak melakukan pengemasan jamu dalam botol dengan baik dan benar. Dari hasil survey yang kami lakukan salah satu dari mereka tidak melakukan penempelan stiker pada botol dengan baik dan benar, dengan alasan karena kondisi mata yang sudah tidak lagi baik, sehingga menyebabkan kurangnya kerapian dalam penempelan stiker. Sedangkan untuk ibu-ibu yang lainnya sudah melakukan pengemasan dengan baik dan benar.

Selanjutnya pada hari Kamis, 13 Agustus 2020, kegiatan yang dilakukan yaitu membagikan jamu penguat kekebalan tubuh dan masker kepada masyarakat Kelurahan Indro. Hasil dari kegiatan ini yaitu:

\section{A. Formula Jamu Penguat Kekebalan Tubuh}

Jamu kunyit Asam merupakan jamu herbal yang baik untuk kesehatan.Di saat pandemi Virus Corona seperti sekarang ini, jamu kunyit asam menjadi salah satu minuman yang baik untuk dikonsumsi. Karena jamu kunyit asam mampu meningkatkan daya tahan tubuh manusia.

Bahan baku pembuatan kunyit asam sangat mudah ditemukan di pasar tradisional. Jadi hal ini memudahkan seseorang untuk mendapatkannya. Bahan baku pembuatan jamu kunyit asam ini adalah kunyit, gula aren, gula putih, asam jawa, garam dan air secukupnya.

1. Proses pembuatan jamu secara tradisional

Jamu tradisional ini biasanya dibuat dengan menumbuk ramuan dalam lumpang atau memakai pipisan. Setelah semua bahan halus selanjutnya ditambahkan air minum secukupnya untuk mempermudah penyarian dan pemerasan. Lalu, air hasil saringan ini dapat langsung diminum. Bila ramuan jamu ini harus direbus dahulu, maka semua bahan yang sudah dicuci bersih ditambah air dalam teko/ panci dan direbus sampai mendidih. 
Edukasi Pencegahan Penularan Virus Corona dan Pemberdayaan Masyarakat Memproduksi Jamu Kekebalan Tubuh di Kelurahan Indro, Gresik

Nursela Putri Andian, Pressa Perdana Surya Saputra

Perebusan ini dilakukan sampai sisa air rebusan menjadi setengah. Lalu, air rebusan ini didinginkan, dan disaring lalu siap diminum. Bila ramuan jamu dibuat dalam bentuk serbuk maka bahannya dibersihkan dan dikeringkan dulu. Lalu, bahan-bahan ditumbuk dan kemudian dicampur, lalu diayak. Serbuk ini selanjutnya diseduh dengan air matang secukupnya dan siap diminum.

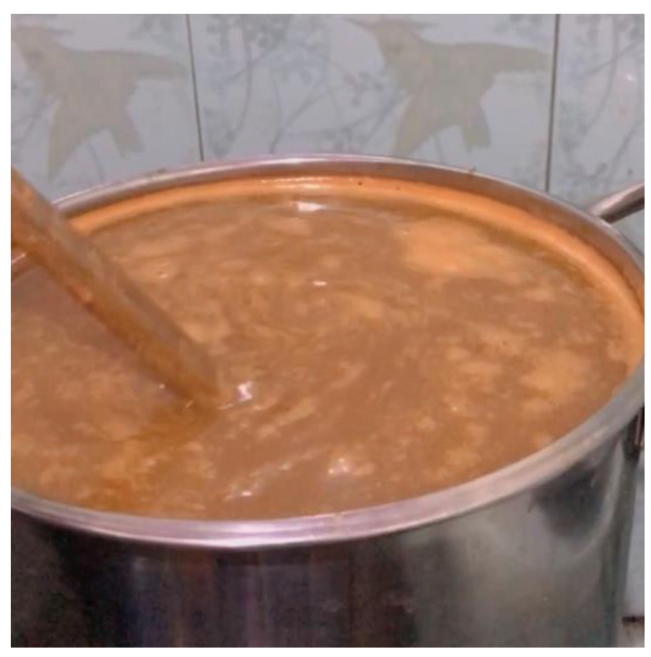

Gambar 1. Proses Pembuatan Jamu

\section{Proses Peracikan}

Penimbangan bahan baku

$>$ Peracikan semua bahan sesuai formula

$>$ Penggilingan bahan baku atau simplisia kering menjadi berbentuk serbuk (penggilingan kasar dan halus).

> Pengayakan dilakukan dengan mesin pengayak sehingga mendapatkan tingkat kehalusan yang diharapkan.

> Penyimpanan serbuk halus di Gudang Setengah Jadi untuk selanjutnya dikemasa atau diolah lebih lanjut.

\section{Proses Pengemasan}

Pada proses ini, pengemasan jamu menggunakan botol berukuran 330ml yang sudah ditempel dengan stiker. Sebelum dimasukkan kedalam botol jamu dibiarkan sekitar 30-45 menit untuk mendinginkan suhu panas pada jamu. Setelah jamu dimasukkan kedalam botol jamu ditutup dan siap untuk diantarkan ke pembeli. 


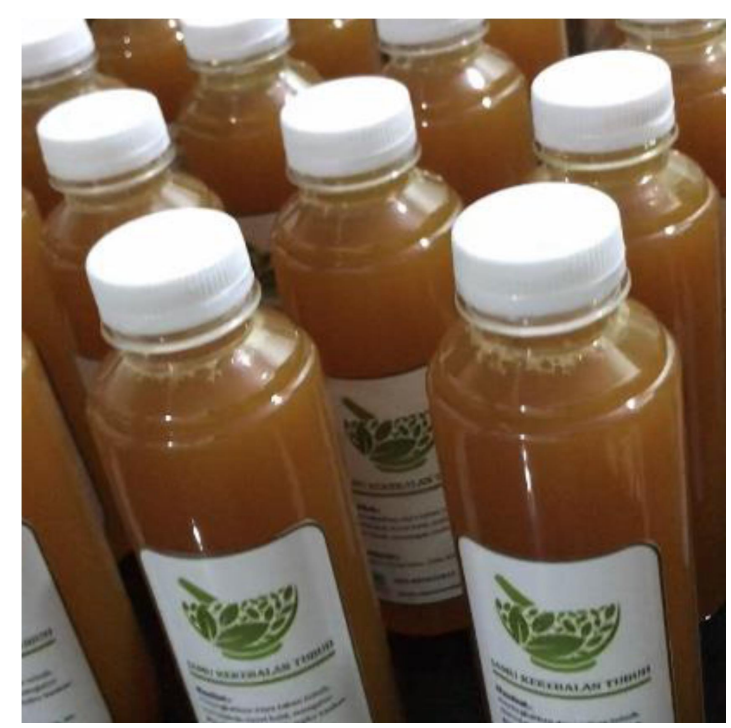

Gambar 2. Proses Pengemasan Jamu

4. Proses Penjualan

> Memperkenalkan produk jamu pada pengguna Instagram

> Mempromosikan penjualan melalui akun Instagram dan Whatsapp

$>$ Melakukan Open Order sistem Pending Order, dengan mencatat nama pemesan dan jenis pengiriman (kurir, cod, ambil ditempat)

$>$ Pengiriman minuman jamu ke konsumen

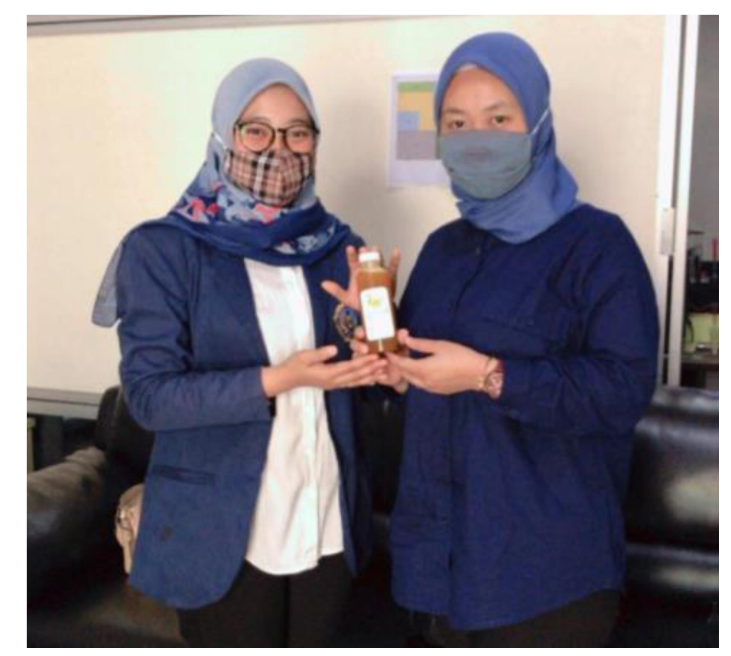

Gambar 3. Proses Pengiriman Jamu pada Konsumen (staff Perusahaan)

\section{B. Biaya Produksi Jamu Kekebalan Tubuh}

Biaya sekali produksi jamu kekebalan tubuh tidak bisa dijadikan harga pasti, karena bahan baku jamu di pasar tradisional harganya relatif naik dan turun. Berikut adalah rincian rata-rata pembelian bahan baku pembuatan jamu sekali produksi. 
Edukasi Pencegahan Penularan Virus Corona dan Pemberdayaan Masyarakat Memproduksi Jamu Kekebalan Tubuh di Kelurahan Indro, Gresik

Nursela Putri Andian, Pressa Perdana Surya Saputra

Tabel 1. Tingkat Motivasi Peserta

\begin{tabular}{llcrrr}
\hline No. & Nama bahan & \multicolumn{2}{c}{ Quantity } & \multicolumn{1}{c}{ Harga } & \multicolumn{1}{c}{ Jumlah } \\
\hline 1. & Kunyit & 3 & $\mathrm{~kg}$ & 15.000 & 45.000 \\
2. & Asam jawa & 1.5 & $\mathrm{~kg}$ & 40.000 & 60.000 \\
3. & Gula aren & 0.5 & $\mathrm{~kg}$ & 110.000 & 55.000 \\
4. & Gula jawa & 2 & $\mathrm{~kg}$ & 16.000 & 32.000 \\
5. & Gula pasir & 2 & $\mathrm{~kg}$ & 12.000 & 24.000 \\
6. & Garam & 1 & $\mathrm{bks}$ & 2.000 & 2.000 \\
7. & Botol 330ml & 100 & $\mathrm{btl}$ & 1.500 & 150.000 \\
8. & Sticker & 100 & $\mathrm{pcs}$ & 300 & 30.000 \\
9. & LPG & 1 & tbg & 22.000 & 22.000 \\
\hline \multicolumn{7}{c}{ Total } \\
\hline
\end{tabular}

\section{KESIMPULAN DAN SARAN}

Kesimpulan Penyuluhan tentang pencegahan penyebaran Virus Corona dan pemberdayaan ibu-ibu RT 6 Kelurahan Indro sangatlah penting. Kegiatan ini mengaplikasikan bagaimana cara pencegahan penyebaran Virus Corona dalam kehidupan sehari-hari dan cara menanggulangi masalah dengan cara yang sederhana yaitu pembuatan jamu kekebalan tubuh. Selain itu masyarakat RT 6 Kelurahan Indro juga dapat bertahan untuk mendapatkan penghasilan di saat pandemi wabah Virus Corona seperti sekarang ini. Dari kegiatan pengabdian ini, diharapkan ibu-ibu RT 6 Kelurahan Indro dapat melanjutkan penjualan jamu kekebalan tubuh.

\section{DAFTAR PUSTAKA}

Pambudi, R. S., Ariastuti, R., Rusita, H., \& Surakarta, U. S. (2020). Abdimas galuh. 2(September), 117-120.

Remaja, P., Panti, D. I., Lubuk, A., Adolescents, C.-I. N., Panti, A. T., \& Lubuk, A. (2020). Abdimas galuh. 2(September), 158-164.

Darmalaksana, W., Hambali, R. Y. A., Masrur, A., \& Ushuluddin, F. (2020). Analisis Pembelajaran Online Masa WFH Pandemic Covid-19 sebagai Tantangan Pemimpin Digital Abad 21. 1-12.

UMG. (2020). Buku Panduan KKN Genap Pencegahan Covid-19 Untuk Mewujudkan Kehidupan Baru ( New Normal ). Universitas Muhammadiyah Gresik, 37-40.

Murdijati gardjito, Eni Harmayani, Kamilia Indraputri Suharjono. (2019). Jamu Pusaka Penjaga Kesehatan Bangsa, Asli Indonesia.

Faisal M. Sakri, Yusuf Al-Madiuny. (2012). 1001 Khasiat \& Manfaat Jamu Godog; Untuk Segala Macam Penyakit 